THE

\title{
JOURNAL OF GEOLOGY
}

\author{
JULY-AUGUST, 1895.
}

NOTE ON THE GLACIAL DEPOSITS OF SOUTHWESTERN ALBERTA.

In the Geology and Resources of the Forty-ninth Parallel (1875), the writer first gave some account of the superficial deposits and glacial phenomena of that part of the Great Plains now included in the district of Alberta. This was followed, in the Report of the Geological Survey of Canada for 1882-84, by a somewhat more complete presentation of the facts relating to the same region. Since that time considerable areas of the adjacent plains have been examined by Messrs. McConnell and Tyrrell, much further information has been obtained respecting the Cordilleran region and many very important advances have been made in the study of the glacial period in North America generally. It thus appeared to be desirable that some further examination should be made, by way of revision and addition, in this region in which the Great Plains border upon the Rocky Mountains, and with this object, the writer, accompanied by Mr. R. G. McConnell, spent some time there in June I 894.

The main points which seemed to require attention were those connected with the relation of the eastern and western drift along the slopes of the mountains, the western limit of the former and the nature of this limit. It appeared probable that facts of value might, in particular, be obtained in the Porcupine Hills, which rise to heights exceeding 5000 feet, at a distance of from Vor.. III., No. 5. 
twenty to thirty miles east of the Rocky Mountains, where, if anywhere, the highest margin of the glacial deposits should be marked either by moraines or by beach-lines.

In the course of a much closer examination of these hills than had previously been possible, it was in effect found, that they show a series of terraces, running up from about 3200 feet to a maximum height of 5300 feet above sea level, and that drift from the Laurentian Plateau, on the east and the Rocky Mountains on the west occurs, as well-rolled shingle, up to the highest level of these terraces and no further. The elevation is nearly three times that of the Laurentian Plateau, and the circumstances show that the Laurentian and Rocky Mountain stones reached these high levels at the same time.

A comparison of the highest levels of the drift in several places in southwestern Alberta, indicates the existence of a tract of greatest depression and of subsequent maximum elevation in a part of that district, and probably that of a series of nearly parallel isobases of decreasing amount to the northeastward of this tract, trending east-southeast by west-northwest, but turning to a northwesterly direction (corresponding with that of the mountains) further to the northward.

Whether the upper limits of glacial deposits be accepted as the shore-lines of an extended body of water, as marking the surface level of a mer de glace or as the margin of a glacier-dammed lake, enormous changes of level in the region must equally be admitted.

A search for eastern erratics upon higher parts of the foothills, in certain localities somewhat extends the spread of this drift to the westward, beyond the line drawn for it by me upon previous maps. These erratics in fact become quite sporadic in their distribution on approaching the mountains.

Some years ago, while examining the sections of glacial deposits along the Bow Valley, eastward from the mountains, Mr. McConnell found reason to believe in the existence of a "western" bowlder-clay which changes gradually to the east into the typical Saskatchewan gravels of the plains. This observation has 
now been confirmed, and it follows from it and from the inferior position of the Saskatchewan gravels to all the previously recognized glacial deposits of the plains, that we have in this region no less than three bowlder-clays to reckon with. The earliest of these is derived entirely from the Rocky Mountains and does not, as a bowlder-clay, extend very far from them. The two later bowlder-clays contain stones of mixed eastern and western origin, each variety preponderating in the direction of its origin. A general section of the drift deposits of the region, as now understood, thus shows, in descending order:

I. Silts, sands and gravels.

2. "Upper" bowlder-clay.

3. Inter-glacial deposits.

4. "Lower" bowlder-clay.

5. Saskatchewan gravels derived from "western" bowlderclay.

It is not quite certain to which of these deposits the high-level terraces and shingles correspond, but it appears probable that they may be assigned to the time of the "upper" bowlder-clay or to that of its close. Neither is it yet definitely known whether the "lower" or "upper" bowlder-clay of the plains extends furthest in toward the base of the mountains. In the absence of the inter-glacial beds, no satisfactory means of distinguishing these deposits in isolated exposures has been found.

It is hoped shortly to publish in sufficient detail the observations upon which these preliminary statements depend; but without entering at all into the question of the mode of origin of the several deposits, it may be of interest here to note their possible relation to those of the glacial epochs or stages recently classified by Professor T. C. Chamberlin. The "lower" bowlder-clay of the plains of western Alberta, may I believe be pretty certainly correlated with his first or Kansan formation, in which case the inter-glacial deposits of the Belly River would represent the Post-Kansan interval and the "upper" bowlderclay of the same region the Iowan formation. Like the Iowan 
formation the "upper" bowlder-clay is characterized by abundant associated silty beds, and no extensive moraine-like deposits are known to be connected with either the "lower" or "upper" bowlder-clays. Further eastward, the northern continuation of the Missouri Côteau to the North Saskatchewan may indicate the limit of the Wisconsin formation. It is at least notable that beyond the Côteau a well-marked system of eroded valleys exists, ${ }^{\mathrm{I}}$ which finds its limit at the Côteau in a manner much resembling that ascribed to the valleys of the Post-Iowan interval.

According to the scheme of correlation suggested above, it will be observed that the "western" bowlder-clay must represent an epoch of glaciation antecedent to the Kansan. There can be but little doubt that this corresponds with the time of maximum development of the Cordilleran ice-sheet, but as there was at least one subsequent epoch of important development of this ice-sheet, I would suggest that this stage may be named "Albertan." The Albertan "formation" to comprise both the "western" bowlder-clay and the derived Saskatchewan gravels.

We may further, although with some reserve as yet and provisionally, accept the hypothesis that the Saskatchewan gravels are contemporaneous with the Lafayette gravels, and in this case the suggestion made by Professor C. H. Hitchcock in a late number of the American Geologist ${ }^{2}$ that the Lafayette gravels represent in the East a glacial epoch earlier than any of those of Professor Chamberlin's classification (which it must be remembered is based upon the region of the Laurentide glacier only) would be substantiated. The bowlder-clays of this epoch may have been obliterated by later events in the East, but still remain unchanged along the base of the Rocky Mountains. Professor Hitchcock further suggests in the same note that the two periods of maximum moisture in the Great Basin may correspond with his supposed first epoch of glaciation and the Kansan epoch, a hypothesis which would correspond very well with that here proposed.

'Geology and Resources of the Forty-ninth Parallel, p. 230.

2 Vol. XV., p. 330. 
The migration of the great center of glaciation from the northern Cordillera to the Laurentian Plateau must have been intimately connected with the very notable changes in relative levels which have already been alluded to.

George M. Dawson.

June I0, I 895 . 